УДК 616.1/4-092.19

DOI 10.11603/1811-2471.2017.v0.i2.7651

\title{
СТВОРЕННЯ ФОРМУЛИ СКРИНІНГУ ГІПОВІТАМІНОЗУ РЕТИНОЛУ ПРИ ХРОНІЧНОМУ ПАНКРЕАТИТІ В АМБУЛАТОРНИХ УМОВАХ
}

\author{
○Л. С. Бабінець, І. М. Галабіцька, С. Г. Гайдаржі ${ }^{1}$ \\ ДВНЗ «Тернопільський державний медичний університет імені І. Я. Горбачевського МОз України» \\ 'Районний комунальний заклад «Кременецький центр первинної медико-санітарної допомоги»
}

РЕЗЮМЕ. У хворих на хронічний панкреатит часто розвивається гіповітаміноз ретинолу, який бере участь в окисно-відновних процесах, регуляції синтезу білків, сприяє нормальному обміну речовин, функції клітинних і субклітинних мембран, відіграє важливу роль у формуванні кісток і зубів, а також жирових відкладень. Метою роботи було створення формули прогнозування дефіциту ретинолу на основі встановлених нами предикторних факторів: рівень холестерину, об'єм м'язів плеча, УЗ-критерії та критерії копрограми. Для персоніфікованого прогнозування дефіциту ретинолу в хворих на хронічний панкреатит застосували встановлені попередніми дослідженнями фактори формування і глибини дефіциту ретинолу як показового прояву полінутрієнтної недостатності. Ці показники є доступними для визначення у практиці лікарів первинної медичної допомоги. Запропонована математична модель прогнозування дефіциту ретинолу в хворих на хронічний панкреатит створена на основі доступних для визначення характеристик хронічного панкреатиту. Формулу можна використовувати для виділення груп ризику за виникненням зниження рівня вітаміну А серед хворих на ХП для своєчасного проведення профілактичних і лікувальних заходів з корекції втрати ретинолу, що особливо актуально для рівня первинної медичної допомоги.

КЛючОВІ СлОВА: хронічний панкреатит; скринінг; гіповітаміноз ретинолу.

Вступ. Ендогенні і екзогенні гіповітамінози $\epsilon$ проявом трофологічної недостатності при хронічному панкреатиті (ХП). У хворих на ХП часто розвивається гіповітаміноз ретинолу, який бере участь в окисно-відновних процесах, регуляції синтезу білків, сприяє нормальному обміну речовин, функції клітинних і субклітинних мембран, відіграє важливу роль у формуванні кісток і зубів, а також жирових відкладень. Ретинол має величезне значення для фоторецепції, забезпечує нормальну діяльність зорового аналізатора, бере участь в синтезі зорового пігменту сітківки і сприйнятті оком світла. Вітамін А необхідний для нормального функціонування імунної системи. Застосування ретинолу підвищує бар'єрну функцію слизових оболонок, збільшує фагоцитарну активність лейкоцитів та інших чинників неспецифічного імунітету. Ретинол необхідний для підтримки і відновлення епітеліальних тканин, нормального ембріонального розвитку, харчування зародка і зменшення ризику таких ускладнень вагітності як мала вага новонародженого. Вітамін А бере участь в синтезі стероїдних гормонів, сперматогенезі, $\epsilon$ антагоністом тироксину. Антиоксидантна дія b-каротину відіграє важливу роль в запобіганні захворюванням серця і артерій.

Мета роботи - створити формулу прогнозування дефіциту ретинолу на основі встановлених нами предикторних факторів: рівень холестерину, об'єм м'язів плеча, УЗ-критерії та критерії копрограми.

Для персоніфікованого прогнозування дефіциту ретинолу в хворих на ХП застосували вста- новлені попередніми дослідженнями фактори формування і глибини дефіциту ретинолу як показового прояву полінутрієнтної недостатності: рівень холестерину, об'єм м'язів плеча, Узкритерії та критерії копрограми. Ці показники $\epsilon$ доступними для визначення у практиці лікарів первинної медичної допомоги. За проведеним багатофакторним регресійним аналізом отримали наступну формулу:

$\mathrm{Y}=2,22-0,1 \mathrm{X}_{1}-0,0556 \mathrm{X}_{2}-0,00894 \mathrm{X}_{3}-0,0464 \mathrm{X}_{4}$ $\left(R=0,978 ; R^{2}=0,956 ; F=510,01 ; t=3,41 ; p<0,05\right)$,

де $x_{1}$ - рівень холестерину, ммоль/л;

$\mathrm{x}_{2}$ - кількісне значення УЗД-критеріїв, виражене в балах;

$\mathrm{X}_{3}-$ об'єм м'язів плеча, см;

$\mathrm{x}_{4}$ - кількісне визначення критеріїв копрограми, виражене в балах.

Розроблений нами метод математичного прогнозування апробований у 100 хворих на ХП. Його чутливість у вибірці становила більше 95,0 \%, специфічність - 78,0 \%. Встановленні за формулою значення рівня ретинолу зіставляють із нормою його вмісту в сироватці крові - 1,05-2,09 мкмоль/л.

Висновок. Запропонована математична модель прогнозування дефіциту ретинолу в хворих на ХП створена на основі доступних для визначення характеристик ХП. Формулу можна використовувати для виділення груп ризику зниження рівня вітаміну А серед хворих на ХП для своєчасного проведення профілактичних i лікувальних заходів з корекції втрати ретинолу, що особливо актуально для рівня первинної медичної допомоги. 
Огляди літератури, оригінальні дослідження, погляд на проблему, короткі повідомлення

ЛІТЕРАТУРА

1. Галабіцька І. М. Взаємозв'язки про- та антиоксидантного статусу з клініко-лабораторно-інструментальними критеріями перебігу хронічного панкретиту / I. М. Галабіцька // XVII Міжнародний медичний конгрес студентів та молодих вчених. - 2013. - С. 11.

2. Бабінець Л. С. Роль оксидативного стресу та стану ферментних та неферментних антиоксидантів у пе- ребігу хронічного панкреатиту / Л. С.Бабінець, І. М. Галабіцька, О. М. Пашкудська // Здобутки клінічної та експериментальної медицини. - 2013. - С. 139.

3. Патогенетичне обґрунтування трофологічних впливів комплексної терапії хронічного панкреатиту / л. С. Бабінець, І. М. Галабіцька, Н. Є. Боцюк, С. С. Рябоконь // Лікарська справа. - 2014. - С. 43-47.

\title{
REFERENCES
}

1. Halabitska, I. M. (2013). Vzaiemozviazky prota antyoksydantnoho statusu z kliniko-laboratornoinstrumentalnymy kryteriiamy prerebihu khronichnoho pankretytu [The relationship of pro- and antioxidant status of clinical and laboratory criteria prerebihu instrumental chronic pankretitis]. XVII Mizhnarodnyi medychnyi konhres studentiv ta molodykh vchenykh - XVII International Congress of Medical students and young scientists, 11 [in Ukrainian].

2. Babinets, L.S., Halabitska, I.M., \& Pashkudska, O.M. (2013). Rol oksydatyvnoho stresu ta stanu fermentnykh ta nefermentnykh antyoksydantiv u perebihu khro-

nichnoho pankreatytu [Role of oxidative stress and the state of nefermentnyh enzyme and antioxidants in the course of chronic pancreatitis]. Zdobutky klinichnoi ta eksperymentalnoi medytsyny-Achievements of Clinical and Experimental Medicine, 139 [in Ukrainian].

3. Babinets, L.S., Halabitska, I.M., Botsyuk, N.Ye., \& Ryabokon, S.S. (2014). Patohenetychne obhruntuvannia trofolohichnykh vplyviv kompleksnoi terapii khronichnoho pankreatytu [Pathogenic study trofolohichnyh impact of complex therapy of chronic pancreatitis]. Likarska sprava - Medical business, 43-47.

\section{СОЗДАНИЕ ФОРМУЛЫ СКРИНИНГА ГИПОВИТАМИНОЗА РЕТИНОЛА ПРИ ХРОНИЧЕСКОМ ПАНКРЕАТИТЕ В АМБУЛАТОРНЫХ УСЛОВИЯХ}

\author{
๑Л. С. Бабинец, И. М. Галабицкая, С. Г. Гайдаржи' \\ ГВУз «Тернопольский государственный медицинский университет имени И. Я. Горбачевского МОз \\ Украины» \\ 'Районное коммунальное учреждение «Кременецкий центр первичной медико-санитарной помощи»
}

РЕзЮМЕ. У больных хроническим панкреатитом часто развивается гиповитаминоз ретинола, который участвует в окислительно-восстановительных процессах, регуляции синтеза белков, способствует нормальному обмену веществ, функции клеточных и субклеточных мембран, играет важную роль в формировании костей и зубов, а также жировых отложений. Целью работы было создание формулы прогнозирования дефицита ретинола на основе установленных нами предикторних факторов: уровень холестерина, объем мышц плеча, УЗ-критериев и критериев копрограммы. Для персонифицированного прогнозирования дефицита ретинола у больных хроническим панкреатитом применили установленные предыдущими исследованиями факторы формирования и глубины дефицита ретинола как показательного проявления полинутриентной недостаточности. Эти показатели доступны для определения в практике врачей первичной медицинской помощи. Предложенная математическая модель прогнозирования дефицита ретинола у больных хроническим панкреатитом создана на основе доступных для определения характеристик хронического панкреатита. Формулу можно использовать для выделения групп риска по возникновению снижения уровня витамина А среди больных хроническим панкреатитом для своевременного проведения профилактических и лечебных мероприятий по коррекции потери ретинола, что особенно актуально для уровня первичной медицинской помощи.

КЛЮЧЕВЫЕ СЛОВА: хронический панкреатит; скрининг; гиповитаминоз ретинола. 

PANCREATITIS IN OUTPATIENT BASIS

\title{
@L. S. Babinets, I. M. Halabitska, S. G. Haydarzhi'
}

\author{
I. Horbachevsky Ternopil State Medical University \\ ${ }^{1}$ Kremenets Center of Primary Care
}

\begin{abstract}
SUMMARY. Retinol vitamin deficiency often develops in patients with chronic pancreatitis, which is involved in redox processes, regulation of protein synthesis, promotes normal metabolic function of cellular and subcellular membranes and plays important role in the formation of bones and teeth and fat. The aim was to create a formula for predicting shortages of retinol-based set us predyktornyh factors: cholesterol, the amount of shoulder muscles, ultrasound criteria and criteria coprogram. For personalized prediction of retinol deficiency in patients with chronic pancreatitis have used previous studies established factors of depth and the deficit as a representative of retinol polinutriyentnoyi manifestation of failure. These figures are available in practice to determine primary care physicians. The mathematical model predicting retinol deficiency in patients with chronic pancreatitis is based on available for defining chronic pancreatitis. The formula can be used to isolate high-risk groups for reducing the occurrence of vitamin Among patients with chronic pancreatitis for timely preventive and curative measures to correct the loss of retinol, which is especially important for the level of primary health care.
\end{abstract}

KEY WORDS: chronic pancreatitis; screening; retinol vitamin deficiency. 